\title{
Evaluating the Risks Due to Pathogen Contamination of Salad Vegetables by the Enumeration of Coli forms
}

\author{
Dr. Arturo L. Tapas Jr \\ College of Engineering, AMA International University - Bahrain
}

\begin{abstract}
The presence of coli forms in food has been used as indicator of the sanitary condition of food as well as the working area used in the preparation or manufacture of food products. However, the subsequent evaluation should be dealt with on a case-to-case basis. It could be seen from the data that the collected vegetables contained coli forms ranging from 100 to 220 per gram. This shows that there is a high possibility that the samples have been contaminated by fecal coli forms and so are not fit for human consumption. But then one has to understand that there are other sources of coli forms in vegetables so that it does not necessarily mean that the vegetables are not fit for human consumption. A high coli form content should merit further examinations and investigations as to the sources of coli forms in the vegetables. In this study, it is important to note that the number of coli forms does not depend on which shop is examined but it depends on the type of vegetables. This is an indication of similarities in the handling of a particular type of vegetables. It shows also that the vegetables are coming from the same source. The nature of the vegetables is also important, for example, leafy vegetables will have more coli forms since the leaves may be a good environment for the growth and preservation of bacteria.
\end{abstract}

Keywords: coli forms, vegetable salads, pathogen

\section{INTRODUCTION}

Coli forms in food are a serious problem because it is an real risk to pathogen contamination can be evaluated and indication that food is contaminated with feces. This is prevented.

something to worry about because there are many diseases that can be contracted by an individual from fecal matter. There are many incidences of serious illnesses originating from contaminated food and water. Of particular importance is the vegetables used in salads because they are not cooked and served raw in restaurants. There is therefore a real possibility of people contracting diseases from eating vegetable salads since they are not adequately washed. Contamination of vegetables may come from different sources. The planting until the harvesting of vegetables are known sources of coli forms in vegetables especially if treated wastewater is used in watering or irrigation. The subsequent handling and processing of food such as during transport, cutting, packaging also contribute to a large extent to the presence of coli forms.

The measurement of coli forms in vegetables is an effective way to determine contamination by pathogens. There is an established link between coli forms and pathogens since the two are normally found in guts of both humans and animals. Thus coli form determination in vegetables presents an effective way of evaluating the risks of contracting diseases from eating vegetable salads. The most probable method (MPN) method of coli form determination is an acceptable method of assessing the level of coli forms in the water. It does not need complicated equipment and the laboratory procedure is very simple. It offers a convenient procedure for the monitoring of coli form levels and thus the possibility of a

\subsection{Statement of the Problem}

Nowadays people are consuming more vegetables because of recent issues regarding health particularly obesity. But people do not realize the problems associated with vegetable salads which are usually eaten uncooked. There is a very high risk of vegetable contamination by pathogens because of their varied potential sources. The measurement of the level of coli forms in vegetable salads can be used in the evaluation of the risks associated with the consumption of raw vegetables.

Objectives:

a. To use MPN method in the enumeration of total coli forms.

b. To use the most appropriate MPN dilutions and replicates for the monitoring of coli forms in green grocer's shops.

c. To proposed reasons why coli forms level could be high or to give possible explanation to the levels of coli forms in vegetable salads. In particular to state the possibility of fecal contamination.

d. To make recommendations as to the health implications of the levels of coli forms in the salad vegetables.

Hypothesis

The level of fecal coli forms in the water or food is an indication of the presence of pathogens, although 
vegetables can also be contaminated by soil bacteria which may also be included in the coli form species. For the purpose of monitoring the sanitary conditions of the food being distributed to the public, the use of MPN total coli forms is very convenient and may signal problem areas for a more exhaustive investigation. Low levels of coli forms would mean safe food for human consumption, high levels will not necessarily mean presence of pathogens since coli forms may also come from the soil. Further investigation is necessary. Poor or unsanitary handling of vegetables will be a factor why coli forms could be high. So that we can already see that green grocer's shops selling vegetables for salads should be required to improve handling practices.

\subsection{Significance of the Study}

The monitoring of food to ensure for health and safety reasons is important. The use of MPN in the detection and enumeration of coli forms gives a very cheap and convenient procedure in the monitoring of sanitary conditions in commercial shops involved in the distribution of food for human consumption. In many parts of the world unsafe practices (aside from safety unawareness) is one of the major reasons why problems, accidents and even deaths are happening.

This study will therefore increase safety and health awareness. In the field of education, this topic is very relevant to students. Awareness to health risks and safety would be more appreciated by the students if they are involved in real world situations and problem solving. This is also going to be an introduction to the broad scope of environmental science. The statistical aspects of the study would be very interesting to the students and this could be the starting point for some of them to pursue similar studies or studies with similar methodologies.

\subsection{Scope and Limitation}

In this study, the MPN method is used in the detection and enumeration of coli forms. Microbial counts are enumerated by MPN method because it is can be performed in the laboratory with common glass wares like test tubes, autoclave and incubator. The study will give a range of detection based on MPN three dilutions and triplicates for each dilution. Vegetables used in salads which are not cooked are the focus of this study.

\section{RESEARCH METHODOLOGY}

\subsection{Sampling}

For each shop visited the following vegetables were sampled: lettuce, carrot, jar jeer, tomato, and cabbage. The samples were taken in the morning and were brought to the laboratory immediately in the same day for analysis. Five grocery shops were sampled. These samples of vegetables were bought from the green grocer's shops.

They were not informed that the samples bought were part of study. The shops remained anonymous in the study and were not revealed to anyone.

\subsection{Preparations of Samples and Analysis}

In the microbial analyses of samples, it was necessary that interferences in the analyses were eliminated so as to reduce uncontrolled variances in the results. These interferences were mainly from contamination coming from the use of equipment and glass wares. Contamination from the air could also contribute to the errors in the analysis. To prevent contamination, sterilization was done by autoclaving. All equipment used and all the plastic bags used in sampling were autoclaved for one hour at 125 ${ }^{\circ} \mathrm{C}$ prior to being used.

It was also be insured that the laboratory was cleaned by disinfectants everyday and that air circulation was minimized inside the laboratory. The variability of the results in these shops was computed using standard deviation and $95 \%$ confidence interval $(\alpha=0.05)$. The samples were analyzed for coli forms before washing. The number of coli forms per gram of the sample was computed.

\subsection{Microbial Methods}

The most probable number of coli forms (MPN) was determined using a presumptive test in accordance with the standard methods. The vegetable to be analyzed was first homogenized using an electric blender. A 5-gram aliquot was diluted by adding $10 \mathrm{~mL}$ of the prepared medium Lauryl Tryptose Broth. This was the first dilution tube and labeled as dilution $10 \mathrm{~mL}$. Dilutions 1 and 0.1 $\mathrm{mL}$ were subsequently prepared from this using sterilized distilled water.

It was assumed that in the preparation of the dilutions, there was perfect mixing and the coli forms were now randomly distributed. A 24-hour incubation period followed. The number of positive samples was counted by noting the development of turbidity and production of bubbles. Tapping of the tubes would released bubbles and make them more visible.

The number of positive tubes in each dilution was noted and the MPN determined from the table. Calculation of the result was be expressed in MPN per gram of vegetable sample.

\subsection{Sample Computations}

This sample computation was for a 5 -g vegetable sample. Supposing 442 combination was obtained after incubation. From MPN Index, we read a value of 47 . It meant that this value was the most probable number of coliforms in the first dilution tube. So that we could then simply compute the MPN per gram as follows. MPN per gram was equal to $47 / 5$ ( 9.4 CFU per gram).

\subsection{Analyses of Data}

For each vegetable in a given shop, there were 3 weekly samplings for the month of November 2015. ANOVA was used to analyze the collected data. Normal distribution was assumed. 
2.6 Evaluation of the Risks

3. RESULTS AND DISCUSSIONS

Based on the collected data, the risk to the consumers of

contaminated vegetables was evaluated. Consideration 3.1 Coli form Counts of the Vegetables

was given to the fact that these vegetables were used in the

preparation of salads where the vegetables were not Tables 3.1 to 3.6 show the level of coli forms per gram for cooked. It was qualitatively discussed whether some the five sampled shops and the corresponding ANOVA sources of coli forms like the soil for example could have analysis.

an effect on the analyses of the result.

Table 3.1 CFU/g of vegetables in Shop $1-5$, week 1

\begin{tabular}{|l|r|r|r|r|r|r|}
\hline & \multicolumn{7}{|c|}{ CFU/g of Vegetables } \\
\hline & Shop1 & Shop2 & Shop3 & Shop4 & Shop5 & avg \\
\hline Lettuce & 290 & 210 & 150 & 43 & 290 & 196.6 \\
\hline Carrot & 24 & 43 & 160 & 21 & 290 & 107.6 \\
\hline Jarjeer & 460 & 460 & 210 & 120 & 460 & 342 \\
\hline Tomato & 160 & 64 & 29 & 160 & 210 & 124.6 \\
\hline Cabbage & 460 & 43 & 460 & 160 & 150 & 254.6 \\
\hline
\end{tabular}

Table 3.2 ANOVA analysis of Table 4.1

\begin{tabular}{|c|c|c|c|c|c|c|}
\hline \multicolumn{7}{|c|}{ Anova: Two-Factor Without Replication } \\
\hline SUMMARY & Count & Sum & Average & Variance & & \\
\hline Row 1 & 5 & 983 & 196.6 & 10847.8 & & \\
\hline Row 2 & 5 & 538 & 107.6 & 13669.3 & & \\
\hline Row 3 & 5 & 1710 & 342 & 27120 & & \\
\hline Row 4 & 5 & 623 & 124.6 & 5652.8 & & \\
\hline Row 5 & 5 & 1273 & 254.6 & 37260.8 & & \\
\hline Column 1 & 5 & 1394 & 278.8 & 36207.2 & & \\
\hline Column 2 & 5 & 820 & 164 & 32253.5 & & \\
\hline Column 3 & 5 & 1009 & 201.8 & 25256.2 & & \\
\hline Column 4 & 5 & 504 & 100.8 & 4271.7 & & \\
\hline Column 5 & 5 & 1400 & 280 & 13600 & & \\
\hline \multicolumn{7}{|l|}{ ANOVA } \\
\hline $\begin{array}{l}\text { Source of } \\
\text { Variation }\end{array}$ & $\mathrm{SS}$ & df & MS & $\mathrm{F}$ & $\begin{array}{c}\mathrm{P}- \\
\text { value }\end{array}$ & $\begin{array}{c}\mathrm{F} \\
\text { crit }\end{array}$ \\
\hline Rows & 186253 & 4 & 46563.26 & 2.864315 & 0.058 & 3.0 \\
\hline Columns & 118101.4 & 4 & 29525.36 & 1.816237 & 0.175 & 3.0 \\
\hline Error & 260101.4 & 16 & 16256.34 & & & \\
\hline Total & 564455.8 & 24 & & & & \\
\hline
\end{tabular}

Table 3.3 CFU/g of vegetables in Shop $1-5$, week 2

\begin{tabular}{|l|r|r|r|r|r|r|}
\hline & \multicolumn{7}{|c|}{ CFU/g of Vegetables } \\
\hline & Shop1 & Shop2 & Shop3 & Shop4 & Shop5 & avg \\
\hline Lettuce & 350 & 240 & 150 & 36 & 210 & 197.2 \\
\hline Carrot & 210 & 290 & 21 & 21 & 28 & 114 \\
\hline Jarjeer & 380 & 350 & 240 & 120 & 290 & 276 \\
\hline Tomato & 120 & 43 & 210 & 240 & 160 & 154.6 \\
\hline Cabbage & 360 & 350 & 350 & 110 & 210 & 276 \\
\hline
\end{tabular}

Table 3.4 ANOVA analysis of Table 3.3

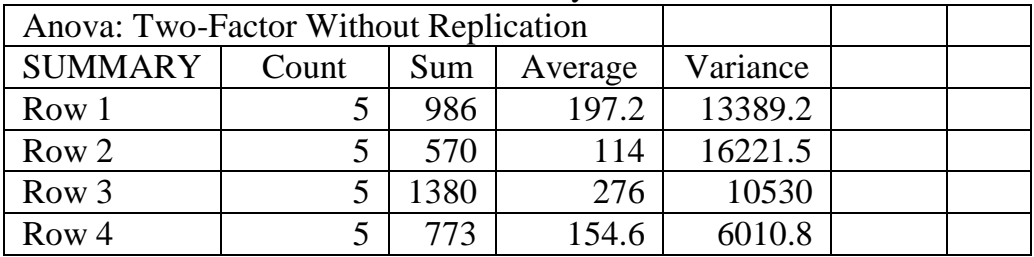


International Advanced Research Journal in Science, Engineering and Technology

ISO 3297:2007 Certified

Vol. 3, Issue 7, July 2016

\begin{tabular}{|l|r|r|r|r|r|r|}
\hline Row 5 & 5 & 1380 & 276 & 12480 & & \\
\hline & & & & & & \\
\hline Column 1 & 5 & 1420 & 284 & 12930 & & \\
\hline Column 2 & 5 & 1273 & 254.6 & 16110.8 & & \\
\hline Column 3 & 5 & 971 & 194.2 & 14643.2 & & \\
\hline Column 4 & 5 & 527 & 105.4 & 7572.8 & & \\
\hline Column 5 & 5 & 898 & 179.6 & 9350.8 & & \\
\hline ANOVA & & & & & & \\
\hline $\begin{array}{l}\text { Source of } \\
\text { Variation }\end{array}$ & SS & df & MS & F & $\begin{array}{c}\text { P- } \\
\text { value }\end{array}$ & $\begin{array}{c}\text { F } \\
\text { crit }\end{array}$ \\
\hline Rows & 104768.2 & 4 & 26192.04 & 3.044209 & 0.048 & 3.0 \\
\hline Columns & 96863.76 & 4 & 24215.94 & 2.814534 & 0.061 & 3.0 \\
\hline Error & 137662.2 & 16 & 8603.89 & & & \\
\hline & & & & & & \\
\hline Total & 339294.2 & 24 & & & & \\
\hline
\end{tabular}

Table 3.5 CFU/g of vegetables in Shop $1-5$, week 3

\begin{tabular}{|l|r|r|r|r|r|c|}
\hline & Shop1 & Shop2 & Shop3 & Shop4 & Shop5 & avg \\
\hline Lettuce & 210 & 240 & 210 & 64 & 240 & 192.8 \\
\hline Carrot & 160 & 290 & 160 & 43 & 460 & 222.6 \\
\hline Jarjeer & 43 & 240 & 290 & 210 & 150 & 186.6 \\
\hline Tomato & 290 & 120 & 160 & 290 & 290 & 230 \\
\hline Cabbage & 290 & 210 & 240 & 210 & 240 & 238 \\
\hline
\end{tabular}

Table 3.6 ANOVA analysis of Table 3.5

\begin{tabular}{|c|c|c|c|c|c|c|}
\hline \multicolumn{7}{|c|}{ Anova: Two-Factor Without Replication } \\
\hline SUMMARY & Count & Sum & Average & Variance & & \\
\hline Row 1 & 5 & 964 & 192.8 & 5409.2 & & \\
\hline Row 2 & 5 & 1113 & 222.6 & 25248.8 & & \\
\hline Row 3 & 5 & 933 & 186.6 & 9012.8 & & \\
\hline Row 4 & 5 & 1150 & 230 & 6950 & & \\
\hline Row 5 & 5 & 1190 & 238 & 1070 & & \\
\hline Column 1 & 5 & 993 & 198.6 & 10634.8 & & \\
\hline Column 2 & 5 & 1100 & 220 & 3950 & & \\
\hline Column 3 & 5 & 1060 & 212 & 3070 & & \\
\hline Column 4 & 5 & 817 & 163.4 & 11186.8 & & \\
\hline Column 5 & 5 & 1380 & 276 & 13130 & & \\
\hline \multicolumn{7}{|l|}{ ANOVA } \\
\hline $\begin{array}{l}\text { Source of } \\
\text { Variation }\end{array}$ & SS & df & MS & $\mathrm{F}$ & $\begin{array}{c}\mathrm{P}- \\
\text { value }\end{array}$ & $\begin{array}{c}\mathrm{F} \\
\text { crit }\end{array}$ \\
\hline Rows & 10530.8 & 4 & 2632.7 & 0.267694 & 0.894 & 3.0 \\
\hline Columns & 33407.6 & 4 & 8351.9 & 0.849226 & 0.515 & 3.0 \\
\hline Error & 157355.6 & 16 & 9834.725 & & & \\
\hline Total & 201294 & 24 & & & & \\
\hline
\end{tabular}

The above tables show that the vegetables from the difference between vegetables but not between shops. different shops that contain some coli forms. This is Table 3.5 show no significant difference between the generally not indicative of any immediate threat to the vegetables and shops. This is an indication that the type of health of the people in the area, but this gives us a hint that vegetables in the salad is important in the evaluation of some preventive measures must be done so as to avoid the the sanitary condition of the salad being used for public occurrence of health issues like food poisoning or consumption. We can say from the data that jar jeer and epidemics in the area. Vegetables sold in the market will cabbage contain relatively higher levels of coli forms than always contain coli forms which could also be fecal coli the other types of vegetables. This could possibly be forms. Tables 3.1, and 3.3 show that there is a significant explained by the fact that the leaves of vegetables can be 
used by the bacteria as a protective environment for them to thrive.

\subsection{Evaluation of Risks}

The presence of coli forms in vegetables is not only an indicator of the sanitary condition of the green-grocer shops. It also indicates the historical handling and exposures of vegetables. For example the coli forms from the soil which is normally harmless might be integrated into the vegetables during harvesting.

The presence of coli forms therefore is not always in indication of unsanitary condition of the green grocers shops. This is kind of evaluation will be helpful in the monitoring of shops and could be used to spot problem areas, for example if there is an occurrence of relatively high levels of coli forms an investigation can be conducted. Washing can effectively remove these coli forms in the water, but it is advisable also to determine the levels of coli forms in the unwashed samples since this will indicate suspected source of contamination. For example a very large number of coli forms in the sample will indicate poor handling.

\section{CONCLUSIONS AND RECOMMENDATIONS}

In the greengrocers' shops, the levels of coli forms depend on the type of vegetables. Some vegetables particularly the leafy vegetables may contain more coli forms than the other types of vegetables because the leaves may provide a protective environment to the coli forms to survive.

The level of coli forms does not depend on the particular shops from which the samples were taken. This suggests that the sanitary condition of the greengrocers' shops is not the major factor in the determination of the levels of coli forms in the vegetables. It indicates that the historical handling or exposure of the vegetables is the important consideration. Although the above conclusion is apparent from the data the levels of coli forms in the vegetables is still an important parameter in the monitoring of the sanitary condition of the greengrocers' shops. It might indicate the occurrence of unpredictable high levels of coli forms in the vegetables so that this might warrant further monitoring evaluation of the sanitary condition of the shops. It is recommended that vegetables that are not cooked and used as ingredients in salad should be washed with water or possibly with boiling water to eliminate the pathogenic bacteria associated with the coli forms in the vegetables. Shop vendors should also observe hygiene at all times to the satisfaction of the health standards of the municipality, since they might contribute to the spread of pathogens in the vegetables and into the consuming public.

\section{REFERENCES}

[1] US Food and Drug Administration (2014), http://www.fda.gov/food/resourcesforyou/healtheducators/ucm0916 81.htm

[2] Falomir MP, Golzalvo D, Rico H. (2010.) "Coliform bacteria in fresh vegetables: from cultivated lands to consumers. Current Research, Technology and Education Topics in Applied Microbiology and Microbial Biotechnology.
[3] Koo HL, Zhi-Dong Jiang, Brown E, Garcia C,Qi H, DuPont HL. (2008) Coliform contamination of vegetables from popular restaurants in Guadalajara, Mexico, and Houston, Texas. Clinical Infectioous Diseases 47 Brief Report.

[4] Gomez CA, Vargas ER,Galvez AM, Roman AD, Castro J. (2013) Presence of coliform bacteria, fecal coliforms, E. coli and Salmonella on corn tortillas in central Mexico. Food Control, Volume 32, Issue 1, pages 31-34.

[5] Adachi JA, Mathewson JJ, Jiang ZD, Ericsson CD, DuPont HL. (2002) Enteric pathogens in Mexican sauces of popular restaurants in Guadalajara, Mexico, and Houston, Texas. Ann Intern Med; 136:884-7.

[6] Tjoa WS, DuPont HL, Sullivan P, et al. (1977) Location of food consumption and travelers' diarrhea. Am J Epidemiol; 106:61-6.

[7] Wood LV, Ferguson LE, Hogan P, et al. (1983) Incidence of bacterial enteropathogens in foods from Mexico. Appl Environ Microbiol; 46: 328-32.

[8] Castro JR, Cerna JF, Mendez ER. (2012) Presence of Faecal coliforms, E. coli and diarrheagenic E. coli pathotypes in ready-toeat salads, from an area where cops are irrigated with untreated sewage water. International Journal of Food Microbiology, Volume 156, Issue 2, pages 176-180.

[9] Wim Jongen. (2005). Improving the Safety of Fresh Foods and Vegetables. Woodhead Publishing in Food Science and Technology, CRC Press.

[10] Ngole V, Mpuchane S, Totolo O. (2006) Survival of fecal coliforms in four different types of sludge-amended soils in Botswana. European Journal of Soil Biology, Volume 42, Issue 4, pages 208-218.

[11] Russell DJ, Majid SA, Tobias D. (2010), The presence of persistent coliform and E. coli contamination sequestered within the leaves of the popular fresh salad vegetable "Jarjeer/ Rocket"(Eruca sativa L.). Egypt, Acad. J. biolog. Sci., 2(2): 1-8

[12] Lynch M,Painter J, Woodruff R, Braden C. (2002) Surveillance for food borne disease outbreaks - United States, (www.edc.gov)

[13] Metcalf and Eddy. (2007) Wastewater Engineering: Treatment, Disposal and Reuse. $3^{\text {rd }}$. McGraw Hill, New York.

[14] Marshall, R. T. (ed.). (1992). Standard methods for the examination of dairy products, 16th ed., American Public Health Association, Washington, D.C.

[15] Eaton, A. D., L. S. Clesceri, and A. E. Greenberg (eds.). (1995). Standard methods for the examination of water and wastewater, 19th ed. American Public Health Association, Washington, D.C.

[16] Vanderzant, C., and D. F. Splittstoesser (eds.). (1992). Compendium of methods for the microbiological examination of foods, 3rd ed. American Public Health Association, Washington, D.C.

[17] U. S. Food and Drug Administration. (1995). Bacteriological analytical manual, 8th ed., AOAC International, Gaithersburg, MD.

[18] Mallmann, W. L., and C. W. Darby. (1941). Uses of a lauryl sulphate tryptose broth for the detection of coliform organisms. Am J. Public Health. 31:127.

[19] Standard Methods for the Examination of Water and Wastewater. (2012). 2nd Edition Book by American Water Works Association/American Public Works Association/Water Environment Federation. Written By Editors: Eugene W. Rice, Rodger B. Baird, Andrew D. Eaton, Lenore S. Clesceri. 